\title{
Consumption, Technology and Adaptation: Care and Repair Economies of Mobile Phones in North India
}

\author{
Assa Doron*
}

\begin{abstract}
On the edges of the digital world in India, there are millions of mobile phone users. To cater for these consumers, an economy of mobile phone care and repair has emerged in almost every town. Through the experiences of consumers and repairers, this article explores technology distribution, service practices and economic opportunity. How do they learn their trade? How do they make a living? And how do they position themselves in relation to the official branded manufacturers and licensed agents? Conceptually, the article is concerned with the nexus between consumer culture, the Indian middle class and the poor and how they engage global capitalism. It argues that middle-class ideologies and practices of consumption are both exclusive and expansive. At the same time, the poor seek to engage this economy by tapping into the unauthorized sector that responds to their demands for local participation in the global economy, while keeping them also at a certain distance from the forms and symbolic capital of the new economy.
\end{abstract}

KEYWORDS: Cell phones; Consumption; Informal economy, Appropriation, Middle class

DOI: http://dx.doi.org/10.5509/2012853563

$\mathrm{B}$ y the end of 2011, India had more than 900 million mobile-phone subscribers. Even if the number of active users at any moment was closer to 600 million, this nevertheless meant that tens of millions of handsets were in circulation in the first decade of cell-phone frenzy. ${ }^{1}$ That

Acknowledgments: Fieldwork in India was made possible by the Australian Research Council (ARC). This paper was initially presented at the "Celling South Asia" conference held at Singapore (February 2011), and the Subaltern Studies Symposia at ANU (August 2011). The most recent version was given at a seminar at the University of Oxford earlier this year (March 2012). I am deeply grateful to Pinku for his ongoing assistance. I would also like to thank the following individuals for their comments at various stages of writing and submitting this article: Dipesh Chakrabarty, David Hardiman, Anand Pandian, Nimmi Rangaswami and Kate Sullivan. I would especially like to thank Robin Jeffrey and Philip Taylor for their incisive suggestions and for helping me shape and refine the argument. I am grateful to the three anonymous PA reviewers for their valuable comments and criticism.

The terms cell phone and mobile phones are used interchangeably, as is the case in India itself.

(C) Pacific Affairs: Volume 85, No. 3 September 2012 
also meant a lot of defective handsets needing maintenance and repair. The article analyzes the way in which people deal with these mangled handsets and their ability to buy and repair such devices. Specifically, the article examines the relationship between the new Nokia Care Centres run by a transnational corporation, and the use of local repair men/shops in north India. It describes the discourse and practice of repairing and the motivations behind continued use of local repair shops that are often at odds with the multinational brand's image of the consumer.

In this paper I argue that relatively poor people in India, able for the first time to own a device so "modern" and manufactured as a mobile phone, contest and reconfigure some of the premises of consumer capitalism, thereby transforming the social life of the technology. ${ }^{2}$

Two key assumptions drive current perspectives on consumption and material culture in India. First is the belief that economically meaningful consumption (i.e., that which integrates India into the global economy) only takes place among the middle classes and that those with limited purchasing power are peripheral to the consumption economy. ${ }^{3}$ Second is the notion that the movement of commodities in the world rarely deviates from the intended trajectory. That is, under the onslaught of global capital, mass consumption inevitably adheres to normative modernist/capitalist visions of a "growing economy" and "profit maximization." 4

In line with recent studies of the Indian middle class (however loosely defined) I show how the middle class seeks to realize their aspirations as global consumers through their participation in an environment characterized by the standardization of commodities and services. ${ }^{5}$ But these aspirations need to be understood in terms of the relations they signify and their connections to particular places, social identities and local networks. Such considerations highlight the tensions, ambiguities and overlaps involved in the formation of a middle class, with its varied patterns of consumption and segregating mechanisms. Such a middle class is both clearly demarcated, yet ill defined in practice.

While the affluent middle class has received much attention as the drivers of India's ballooning consumerism, there is another strand of academic literature - that of the business and management genre-that has embraced

\footnotetext{
2 See Arjun Appadurai, "Introduction: commodities and the politics of value," in The Social Life of Things: Commodities in Cultural Perspective, ed. A. Appadurai (Cambridge: Cambridge University Press, 1986).

3 C.K. Prahalad, The Fortune at the Bottom of the Pyramid (New Jersey: Pearson Education, 2004).

4 Pavan Varma, The Great Indian Middle Class (New Delhi: Penguin, 1998).

5 See Leela Fernandes, India's new middle class: Democratic Politics in an Era of Economic Reform (Minneapolis: University of Minnesota Press, 2006); Ruchira Ganguly-Scrase and Timothy Scrase, Globalisation and the Middle Classes in India: The Social and Cultural Impact of Neoliberal Reforms (London: Routledge, 2009); Sanjay Srivastava, "Urban Spaces, Disney-Divinity and Moral Middle Classes in Delhi," in Elite and Everyman: The Cultural Politics of the Indian Middle Classes, eds. Raka Ray and Amita Baviskar (New Delhi: Routledge, 2011), 364-390.
} 
the poor as the new global consumers. Perhaps the most influential of these studies is C.K. Prahalad's best-selling book, The Fortune at the Bottom of the Pyramid. According to this view, rather than catering for middle-class consumers, "we" - MNCs, governments and the non-government sectorshould direct attention to the masses located at the "Bottom Of the Pyramid" (BOP), whose cumulative purchasing power can energize global growth. Prahalad seeks to challenge the dominant views that dub the poor as "wards of the state," suggesting that given the appropriate prompts, the poor are destined to catapult the global market economy to new highs. Prahalad and colleagues couch their thesis in almost messianic terms, promising a framework that would alleviate global poverty. This could be achieved if only "we" could transform the poor into proper individual consumers. The mechanism for this poverty eradication project is the market economy, duly tuned for the demands of the BOP consumers, who are given affordable choices and self-respect as free individuals actively energizing and engaging in what Prahalad calls "inclusive capitalism." Put differently, by realizing that "the poor represent a 'latent market' for goods and services," the decision makers can help them cast off their social and economic bonds. This will turn them into liberated consumers who are even more adaptable to entering and exploiting the market economy. ${ }^{6}$ Thus, the instability at the Bottom Of the Pyramid where the poor live is corrected by the stability of the market, defined by "rational" categories of commercial exchange. At the same time, the poor will get a taste of equality, as demanding, respected, brand-nameconscious consumers.

There is much to commend in this approach and its laudable quest. Prahalad's book has plenty of examples (many from India) to support an optimistic view of global capitalism. Indeed, the Indian case itself is highly suggestive, given the rapid penetration of cell phones down to the level of the very poor. Yet despite all its lofty claims to empower the citizen-consumer, the arguments rest upon a distorted view of the state, society and market economy. ${ }^{7}$ The harmonious neoliberal vision, where heterogeneous institutions, ideologies and strategies align their interests to activate a "latent market," gives such business studies a strong air of romanticism. In such a vision, the protagonist—the individual entrepreneur-becomes a fetish belief, as the dignified cure for global misery, political mismanagement and uneven geographical development (itself a product of neoliberalism).

In this article I cannot examine the range of "common sense" assumptions underpinning this otherwise highly engaging book, ${ }^{8}$ rather I focus on class

\footnotetext{
$6 \quad$ C.K. Prahalad, The Fortune at the Bottom of the Pyramid, xi, 5.

See Philippa Williams, Vira Bhaskar and Deepta Chopra, "Marginality, Agency and Power: Experiencing the state in Contemporary India," Pacific Affairs 84, no. 1 (2011): 7-23.

8 See David. Harvey, A Brief History of Neoliberalism (New York: Oxford University Press, 2005) and Ha-Joon Chang, 23 Things They Don't Tell You About Capitalism (London: Penguin, 2010).
} 
relations and the figure of the individual consumer/producer in contemporary India. One of my contentions is that even when equipped with the liberating technology of mobile phones, and enhanced access to information, the underprivileged remain excluded and are alienated from spaces where the "wizardry of consumer seduction" is exercised. ${ }^{9}$ This becomes evident when looking at the mobile-phone service centres that embody middle-class values, ideologies and practices, constituting projects of middle-class advancement and social distancing. ${ }^{10}$

For the underprivileged, it is the unauthorized economy that responds to their demands for local participation in the global economy. This section of society resorts to its own resources, ideologies and practices, found in the "informal" sector of the mobile phone industry. There, a street-side society interacts with the corporate-driven, expiry-date-limited economic model based on "planned obsolescence." The repair economy is innovative but subversive; it is constrained by scale but propelled by its flexible ability to deal with changing inputs and to cater for local needs and desires. Some of these informal practices are illegal, breaching tax and copyright laws. They are part of what Sundaram calls "pirate modernity." ${ }^{11}$ Unlike Sundaram, however, my concern is not the "modernity" of these practices but their connection to "tradition." The bricouleur working at the lower end of the mobile phone economy is premised on notions of trust, and other more localized forms of capitalism embedded in kinship relations, for gaining a skill base and consolidating the business of the poor (see Ranagaswamy, this issue).

In India there are thousands of street-side repair shops catering to the less affluent population, people for whom the cell phone is perhaps their first and only global commodity. For them, maintaining and repairing the phone is primarily done in the informal sector. These are places of social economic interaction where self-taught technicians recover and reuse mobile phones; they are also places of disorder where the plans of global capitalist enterprises are fragmented and adapted to suit the needs of tens of millions of Indians. By investigating this "invisible" economy, as opposed to the formal ones that have emerged with the entry of MNCs, this essay also attempts to illuminate one dimension of India's integration into the world economy.

Two different sorts of places are examined: the branded phone service centres and the street repair stalls. I primarily focus on Nokia because it was India's first mobile phone company, setting the industry standards as its dominant player, despite mounting competition by giants such as Samsung

\footnotetext{
9 Arvind Rajagopal, "The Violence of Commodity Aesthetics: Hawkers, Demolition Raids, and a New Regime of Consumption," Social Text 19, no. 3 (2001): 99.

10 Cf. Mark Liechty, "Carnal Economies: The Commodification of Food and Sex in Kathmandu," Cultural Anthropology 20, no. 1 (2005): 1-38.

11 Ravi Sundaram, Pirate Modernity: Delhi's Media Urbanism (New York: Routledge, 2010).
} 


\section{Consumption, Technology and Adaptation}

and LG. In the Nokia Care Centre, a global corporate environment structures a client's ideas about the self, and modes of being and knowing the world. In these places a person experiences the procedures of audit, surveillance and evaluation, which constitute what Voice describes as "'dividing practices,' separating middle-class consumers from the rest." ${ }^{12}$ The second context-the street repair-treats the relationship between humans and technologies as being informed by wider social practices and community-based relations.

I present the repair economy of mobile phones in India as a series of oppositions, which I use as heuristic instruments and foils: formal/informal; old/new economies; developing/developed; tradition/modernity. Such dichotomies inevitably distort more historically and socially complex phenomena, yet they remain useful. ${ }^{13}$ They reveal attitudes towards the repair of digital media: the cultural function, meaning and value given to "things" as objects inseparable from human agency and the social world. To this end, I avoid labelling India's repair economy as "backward" or as a marker of "incomplete development." Instead, I consider this repair economy as exhibiting a particularly Indian inflection, embedded in specific economic, cultural and political circumstances. This is not simply the transplanting of global capitalism to the periphery, nor is it an instance of "local" resistance to the capitalist economy, emerging out of any culturally and territorially stable practices, institutions or ideologies. Rather, these are processes and spaces that are mutually dependent. They defy a unified view of modernity and highlight the heterogeneity of experiences of consumption (both culturally and politically) that render such transnational commodities meaningful.

The article begins with the consumer-care services revealed in the practices of the famed brands of global capitalism. This discussion is based on my experience in the Nokia Care Centre in Banaras during an attempt to repair my ailing mobile. This account brings into relief the contingent nature of the "informal" repair economy that I examine in the second part of this paper. By pitching the two-the "local" repair economy against its "global," multinational counterpart-the ethnography seeks to map the spaces between the apparent dichotomies of formal/informal economies, stressing overlaps and interdependence, as both are shaped by ideology, economy and the cultural aspects of consumer capitalism.

Malcolm Voice, "Shopping Malls in India," Economic and Political Weekly 42, no. 22 (2007): 2055. As Birla has illustrated in her brilliant examination of capitalism under British rule, indigenous commercial practices, largely constituted through kinship forms, were reframed along principles and values of economic rationalism that suited colonial desires to produce standardized market practices and procedures. As a result, what she calls "vernacular capitalism" was brought under the timeless rubric of "tradition" and "culture," and served as further evidence for their backwardness and difference. Ritu Birla, Stages of Capital: Law, Culture, and Market Governance in Late (Durham: Duke University Press, 2009). 


\section{The Nokia Care experience}

During fieldwork in north India in October 2009, I used my Nokia N2610 phone, purchased in Australia. After a few days the phone stopped working. ${ }^{14}$ It was unusually hot in Banaras-the temperatures were above 35 degreesand it was very dusty. On the advice of friends, I opened the phone, cleaned the battery and left it to air under the ceiling fan for a few hours. But the phone did not respond. I was told I had two options: to visit the Nokia service centre, Nokia Care, or seek help from one of the many fix-it people (mistriis). While the latter option was tempting-especially in the name of fieldwork-I decided in favour of the Nokia Care Centre. This was, after all, my personal phone with all my contacts, family pictures, appointments and messages accumulated over years.

Nokia was the leading cell phone brand from the time the mobile phone arrived on the subcontinent at the end of the twentieth century. Its phones had a reputation for quality, reliability and, unlike many competitors, the ability to withstand the hard, rough conditions of India. Nokia also had a wide distribution network and, like other brand names (e.g., Samsung, LG, Sony, etc.), used Bollywood stars as brand ambassadors in its advertising campaigns. Nokia was everywhere. Not surprisingly, once I decided to go to Nokia Care, the rickshaw driver knew exactly where to go.

Banaras has three official Nokia Care Centres and the nearest was in a building just off the busy Bhelapur Crossing. The two-story building housed the well-known Kerala Café, frequented by young people and families looking for a relatively cheap and nourishing south Indian meal. But the shops surrounding Kerala Café, which used to sell a variety of merchandise from home appliances to shoes and clothes, had been replaced by mobile phone shops selling all things mobile-related, including memory cards, battery chargers, headphones and even a "full-body" (i.e., handset frame) lamination designed to prevent the wear and tear of weather and working people's lives.

Arrows on the wall of the staircase directed customers to the Nokia Care Centre on the second floor. The walls were adorned with posters, and each floor housed smaller Nokia shops with signs in Hindi and English that they

14 My ongoing research in India, and in Banaras more specifically, alerted me to the huge uptake of mobile phones and their implications on various aspects of social life. This was especially the case amongst poorer communities, such as the boatmen of Banaras, with whom I have maintained connections over the last decade. Prior to the mobile phone, the majority of people in India accessed telephony only through the Public Call Offices (PCOs); many amongst the boatmen still do not have access to electricity or water in their homes, let alone landline phone connections. Yet these days almost all own mobile phones. Ethnographic fieldwork for this project was carried out over a period of three years (October-November, 2009; June-July 2010, and January-February 2011), where I visited places in the north and western parts of India, conducting semi-structured interviews and participant observation as part of a wider investigation into the effects of mobile phones on economies, social practices and social and political institutions in India. See Robin Jeffrey and Assa Doron (forthcoming), The Great Indian Phonebook: How the Mass Mobile Changes Business, Politics and Daily Life (London: Hurst, 2012). 
too were "authorized service and sales centres." Nokia Care was the most celebrated of all the businesses. Several large potted plants led to a lofty cardboard archway behind which was a larger-than-life poster of the Bollywood star, Priyanka Chopra, sporting her Nokia cell phone and dressed in a glittering evening gown. At the door a security guard doubled as the person who handed numbered tickets to arriving clients to assign them their place in the queue. The reception area was spacious and clean, its white shining tiles giving it a sense of order. All the waiting customers were men, seated on trendy blue plastic chairs and gazing at the muted flat-screen TV (see figure A).

The receptionists were the initial point of contact for the customer. Separated by glass screens, four women registered on their computers the details related to customers and their mobile phone problems. Behind them was a smoky-white glass barrier, where one could glimpse several cell phone technicians at work. They too had neatly arranged work stations, with various instruments to identify problems and repair phones. The customer did not interact with these technicians; all customer care was through the receptionists. Once my number flashed on the electronic board, I approached one of the receptionists, Sita, a young woman in her early twenties who had recently begun working for Nokia in customer care. She listened attentively to my description of the lead-up to the sudden death of my phone; as she listened, she typed. She took the phone, examined it and passed it across the counter to a technician who dismantled it for appraisal. This took no longer than five minutes. After that Sita gave me a form to fill out and sign, including my personal details and the cost of evaluation of Rs 100, with an estimated repair cost of Rs $350 .{ }^{15}$ The phone, she reassured me, should be fixed and ready for pickup by six that evening.

I proceeded to the cashier for payment and lodged and signed a few more forms. On the way out I noticed a shrine with a photograph of the proprietor's guru, adorned with fresh flowers. Beside this stood a medium-sized, sparkling clean and well-filtered fish tank with several goldfish swimming about. By the door, next to the security guard, a large white board displayed the sentence: "Has Nokia made you smile today?" On the upper left corner a blue-boxed caption noted: "Nokia: India's most trusted brand." The board had yellow magnetic happy faces on it, under some of which feedback notes were placed by customers, many in English, others in Hindi; many satisfied, others not so happy with the "Nokia Care" experience.

I left happy and relieved that my phone would be fixed by day's end. Outside, the steamy, noisy and polluted atmosphere was a fitting return to an "older" India after my satisfying experience with the "new," improved, big-brand India that Nokia and global capitalism had brought. Little did I know that I would be returning to Nokia Care three more times that week

15 The exchange rate at the time was Rs $46=\mathrm{US} \$ 1$. 


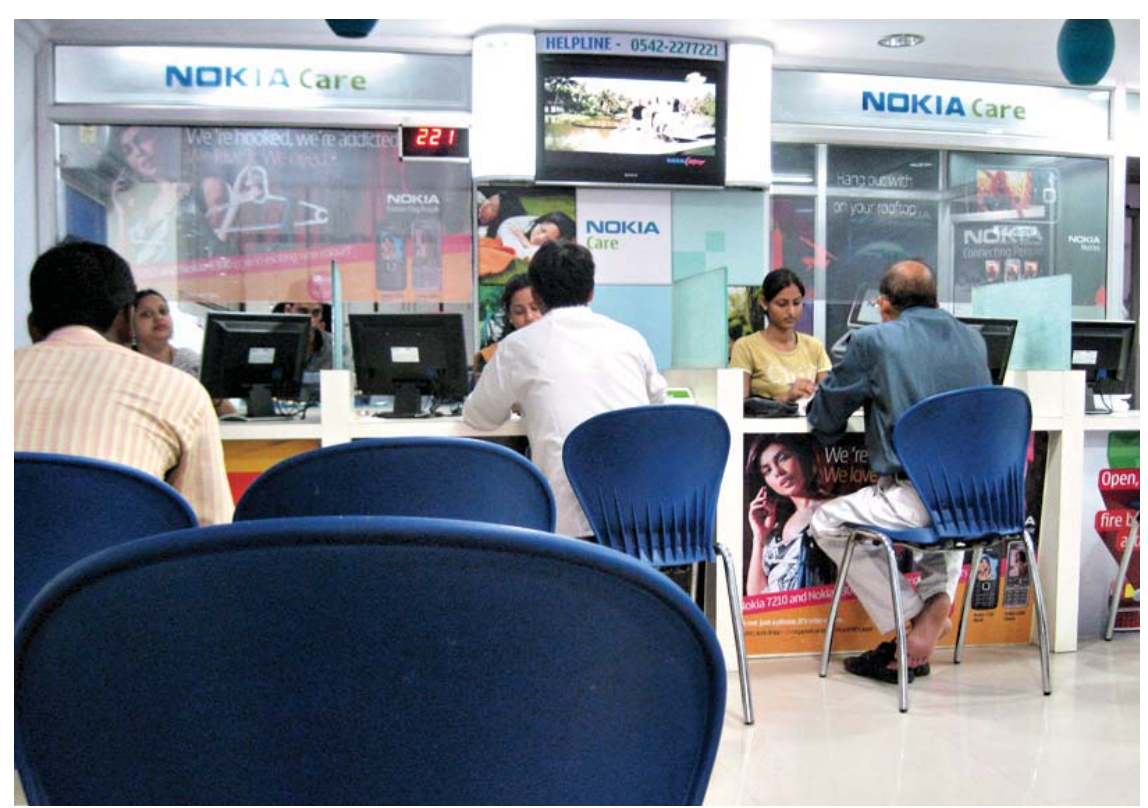

Figure A The Nokia Care Centre in Banaras, near Bhelapur Crossing, October 2009

until eventually opting to fix my mobile at the repair walas (fix-it people) on the street. Each time, I was told the phone would be ready tomorrow. On the third visit, I took the phone back and presented it to a street-based mistri. In a few hours, the mistri confirmed the Nokia diagnosis that a new motherboard was required and I chose to buy a cheap non-branded ("China Mobile”) from the grey market in Banaras' Daal Mandi. ${ }^{16}$

The experience dramatized the choices that can be forced on an owner of a mobile phone: the sleek Nokia Care Centre or the dusty turmoil of the bazaar? The sanitized customer-care centres were similar to multinational chain stores all over the world and a testimony to the homogenizing effects of globalization. Banaras, the most famous city of Hindu faith, got its first McDonald's in 2005. But the spread of global capitalism is not onedimensional. Homogenization of practices proceeds unevenly and is shaped by local conditions and preferences. ${ }^{17}$ Certain values, ideologies and modes of conduct, however, bear the marks of global modernity. The equal rights of individuals is one such idea: the belief that individuals have rights and responsibilities regardless of their place in society. In the case of Nokia Care,

16 Daal Mandi refers to any large market in UP which deals with a variety of goods, traditionally food items, hence the name Daal (lentil) Mandi (market). Nowadays, there is a Daal Mandi in many towns of UP and these places sell both second-hand items and semi-illicit commodities.

17 See Thomas. H. Eriksen, Globalization: the key concepts (New York: Berg, 2007). 


\section{Consumption, Technology and Adaptation}

this translated into the idea of a first-come, first-served, carefully managed queue.

Significantly, with the advance of consumer capitalism and the affordability of mobile phones, engaging with the corporate world is no longer the preserve of the upper classes in India. Increasingly, middle and lower-middle classes participate in this consumer economy. Places such as the Nokia Care Centre stress customer satisfaction and loyalty to corporate identity. The customer becomes familiar with the technical and social protocols of a certain type of consumer-driven world. These inspire acceptance (if not adoption) of new modes of seeing and being in the world, such as embracing the behaviour of the queue, interacting with other people as individuals, possessing rights and being bound by contracts. This "individuating" dimension opposes a more "relational" mode of being associated with the "Indian way of life" bound by family relations, status, duty and obligations, rather than abstract rights and contracts..$^{18}$ Of course, individual/relational dichotomies are debatable, and significantly depend on local situations, as generations of anthropologists of South Asian personhood have long argued. My aim is to highlight the mechanisms employed in such spaces of maintenance and repair of MNCs as Nokia Care that seek to re-orient and socialize people into new forms of consumption and into "appropriate" ways of consumer behaviour.

Many middle-class people are increasingly entrusting their valuable mobile devices to the hands of these "more reliable," expert-based centres. The disjuncture between places such as the Nokia Care and the street-repair economies are stark. Yet as the following conversation with an informant about his faulty mobile phone demonstrates, some people do not see the two options- the Nokia centre and the repair walas—as mutually exclusive: ${ }^{19}$

SUNIL: When my phone broke I took it to the Sony service centre. The person at the counter told me that to fix this model they'll need to import the part and it will be very costly and would take more than two weeks. I did not have the time or money for this so I decided to take it to the mistri.

$\mathrm{AD}$ : What did you think about needing to wait in line at the care centre?

SUNIL: There was a queue there too, but all the places are like this, these companies come from the west, and like any civilized society in the west they have queues, things that need to be organized, with numbers... Here in India I don't have to queue because relations (sambandh) are more personal. You see, in India more work can be done through personal connections.

$\mathrm{AD}$ : What do you mean?

\footnotetext{
18 Ira Raja, "Rethinking Relationality in the Context of Adult Mother-Daughter Caregiving in Indian Fiction," Journal of Aging, Humanities and the Arts 3 (2009): 25-37.

19 All names have been changed to maintain anonymity.
} 
Pacific Affairs: Volume 85, No. 3-September 2012

SUNIL: If you have good relations with the shop owner or with the repair wallah, your mobile will be fixed first, if not then you will have a bit of trouble and you will need to wait until your number comes up.

AD: So when you left the Sony service centre where did you go to fix your

mobile?

SUNIL: I went to one boy I know in my mohalla (neighbourhood). He deals with second-hand mobiles and also repairs them. He checked my mobile and said he couldn't repair it himself, as it looked like a major problem. So he said he'd take it to Daal Mandi and let me know the problem and cost by that evening. He later called to tell me that it would cost around Rs 700 to repair because it was a problem with the "mother board," and it would be ready the next day. My father was upset and said I should not let the mistriis in Daal Mandi fix my mobile because they replace the good parts with used ones. But I decided to do it anyway and the mobile was repaired. They replaced the screen and did software formating too. But probably because they had an older version which did not match my mobile, some features like my camera and torch still don't work well.

Sunil is an upper-caste, lower-middle-class man in his early 30s. People of his socio-economic status have more choice than the poor about where they might take their mobiles for maintenance and repair. They too run a risk: once the seal is broken and the handset is tinkered with in an unauthorized setting, service centres refuse to honour a warranty and refuse to fix the phone-as I was informed when I mentioned such an option on one of my visits to Nokia Care. Sunil seemed comfortable in both environments. While the branded service centre was his first port of call, he did not shy away from the street-repair economy. People like Sunil are able to benefit from the two seemingly distinct modes of repair: formal and informal.

\section{The queuing class}

The electronic queue in such mobile phone service centres is an attractive feature, especially for those who find the experience of the "common Indian queue" disorderedly, and distressful. The Indian queue, suggests Corbridge, is underpinned by a measure of state-scarcity, "whether in terms of personnel, training, record keeping or technology." ${ }^{20}$ The Nokia Care queue can therefore be seen as representing the alternative: the abundance of capitalist consumption, unrestricted by administrative red tape, state parsimony and corruption, which many in India consider as part of state power. For many visitors to these care centres, this is the first and perhaps primary setting in

20 Stuart Corbridge, "Waiting in line, or the moral and material geographies of queue-jumping," in Geographies and moralities: international perspectives on development, justice and place, eds. R. Lee and D.M. Smith (Oxford: Blackwell, 2004), 195. 


\section{Consumption, Technology and Adaptation}

which they encounter orderly queuing. Sunil's association of queues with Western modernity and civility fits within the wider arrangement of order in the Nokia Care Centre-its gleaming floors, and neat (and gendered) division of labour. The technicians, maintenance, marketing and design and service provision operate in a compartmentalized and impartial manner.

At the same time the clientele bolster middle-class conceptions of exclusivity, efficiency and modernity of service. In choosing to go to the care centre, they are reproducing middle-class ideals and practices. The ethics of the queue are symbolic as much as they are practical. They rely on an egalitarian sensibility where a person occupies the same position as others in the queue with little regard for their socio-economic status or social connections (personal, family, community). These are consumers prepared to wait for their cell phone to be fixed-it's worth it for them. The queue is maintained by individuals embodying it, not just "culturally" falling into line; rather, they are actively reproducing the queue-etiquette. But this can only be achieved where there is enough personnel and infrastructure to assure people that their turn will come, regardless of their status.

Following C.K. Prahalad's logic, the "impersonal" queues of Nokia Care should be very attractive to the Bottom Of the Pyramid consumer, who begins to get a taste of what equality and citizenship is supposed to be about. Yet as I have shown, the time and money spent (the evaluation alone costs Rs 100) along with the "aesthetic at work" in such spaces serves to alienate the majority of the poor. ${ }^{21}$ Not surprisingly, none of my informants amongst the lower class ever reported visiting these places.

There are other ways in which service centres socialize the consumer and introduce new practices and knowledge. Consider, for example, the contract, represented by the receipt one receives at the end of a transaction. With their receipt in hand, customers feel endorsed and relieved, guaranteed of Nokia's international standards and confirmed in their own participation in what Herzfeld called the "global hierarchy of value." ${ }^{22}$ Even the feedback mechanism, which in the street-side economy is based on word of mouth, in Nokia Care is replaced by small notes attached to smiley-face magnets on a board. This prescribed and restricted form of feedback gives clients a sense of agency in their interaction with abstract entities like multinational corporations. The care centres are set up to resemble "Western" ones. Having one's mobile repaired there may not be as quick or convenient as getting it fixed at the local street-repair shop, but it promises certitude, reliability and accountability, for which people are increasingly willing to pay.

These mobile care centres need to be understood as symbolic as much as functional. Here, aspiring middle-class consumers reproduce the ideals,

21 Arvind Rajagopal, "The Violence of Commodity Aesthetics," 99.

22 Michael Herzfeld, The Body Impolitic: Artisans and Artifice in the Global Hierarchy of Value (Chicago: University of Chicago, 2003). 
values and practices of the multinational corporation, such as Nokia or Samsung, or service providers such as Vodafone or Airtel. All promote uniformity in appearance, service and tastes, with particular ideas about property rights and ownership. "Brands" such as these have carried massproduced products to customers for two hundred years.

Of course, brands such as Hindustan Unilever have been operating in India for almost a century. They too have sought to attract customers through friendliness, dependability and-most important—recognition: the very essence of branding and mass consumption/production. In the past two decades, however, scores of organizations (national and multinational) have entered the Indian market to expand sales. To do so, they have had to create consumers and convince them of the worth of their brand. The branded mobile care centre thus seeks to promote the notion of a new India, found in the glitzy malls, with ideals of freedom, independence, equality, individuality and empowerment. This is expressed in the position women occupy within the service centres. The women are receptionists who wear modern attire (jeans) and address customers in formal Hindi (rather than the local Bhojpuri of Banaras). It is not that gender assumptions are absent. On the contrary, they are present in the same fashion as in the "West," with an association between masculinity and technology. But the very presence of women transforms gender assumptions, so that gender distinctions are "naturalized." They help to make this modern setting. This is modern India: women participate in new professions and in salaried jobs. And this India itself reproduces gender distinctions: female receptionists; male engineers and technicians.

An additional layer to this specialized economy is represented by the Nokia engineers. They are class-room trained and have regulated work hours. Such formalities reinforce the association between modern practices and acquisition of skills and specialization, as opposed to the hands-on, "tinkering," task-based work of the street. ${ }^{23}$

Replacing contingency with certitude is important. The protocols and modes of dress and address of the Nokia Care Centre allow the middle classes to segregate and distinguish themselves from others. As Sunil suggests, these care centres confirm pre-existing expectations about the civilizing effects of such places of modernity and globalization. Indeed, the only distinctively local element in the care centre that I visited was the small shrine, displaying the picture of the guru near the entrance - a hyper intense expression of "the social." The franchise holder appeared to be stamping, as much as the Nokia people would let him, his own values on the centre: values that would appeal to, and not offend, his customers. This marker of the social bore witness to his piety, and upheld the "traditional" values of a devoted Hindu.

23 See E.P. Thompson, "Time, Work-Discipline and Industrial Capitalism," Past and Present 38 (1967): 56-97. 


\section{Consumption, Technology and Adaptation}

It also represented a statement that one's well-being and success is achieved by submission to one's personal guru. The ideology of the guru is juxtaposed against the otherwise "Western" material practices increasingly evident in India's surging retail industry.

The "choreography of modern consumerism" was attractive to middleclass consumers, though it largely alienated and intimidated subaltern classes, such as the boatmen whom I knew. They never visited such places. This was not to say they were unaware of what a warranty meant or that they did not own brand-name phones. But the unauthorized sector offered more possibilities, both materially and symbolically, and with fewer restrictions. This unofficial realm was where the majority of people still went for repair of their mobile devices-just as I ended up doing.

\section{Street repair in Lucknow}

Lucknow, the capital of Uttar Pradesh, bustles, and Hazratganj, its heart, pulsates. Huge billboards, snail-paced traffic, modern shopping complexes, and multiplexes sit beside historic buildings and time-tested restaurants serving Mughlai cuisine.

In June 2010, it was over 40 degrees when I met Saif Siddiqui and his brother-in-law, Salim. Their tiny 1 x 3 metre shop was one of three in a row, all occupied by men repairing mobiles. In the following days I visited them a number of times, leaning on the counter that separated them from passersby in the street. Saif and Salim were Muslims in their mid-twenties. Saif opened the shop in 2005 after a friend suggested that it would be a more profitable business than the jeans-and-sunglasses shop they operated at the time. Soon after, he explained, a few more repair shops opened next to his. Saif completed tenth standard at school (15/16 years) and gained his mobile repair skills from a friend, rather than in a training institute. According to Saif, it took him three years to become competent in fixing almost all types of mobile phones, including the latest "smart phone" models. In 2010, his road-side shop was full of handsets in different states of dysfunction; he bought them cheaply from a wholesaler.

Saif and his brother-in-law were known as mistriis or artisans (see figure B). Throughout the day they engaged in "grooming," fixing and adjusting all types of handsets for people off the street. The transaction was fairly straightforward. Saif and his partner sat behind the counter and interacted with their customers, who stood on the pavement, sometimes inspecting the devices on display in their very-mini showroom. The customers explained the fault, and asked for a quick evaluation of the problem. The most common faults, Saif said, included water damage, connectivity problems and screen or recharging faults, often caused by moisture. The moisture problem was usually solved by prying open the phone and dipping the motherboard in a bucket of chemicals which emitted an unpleasant odour that Saif kept next 


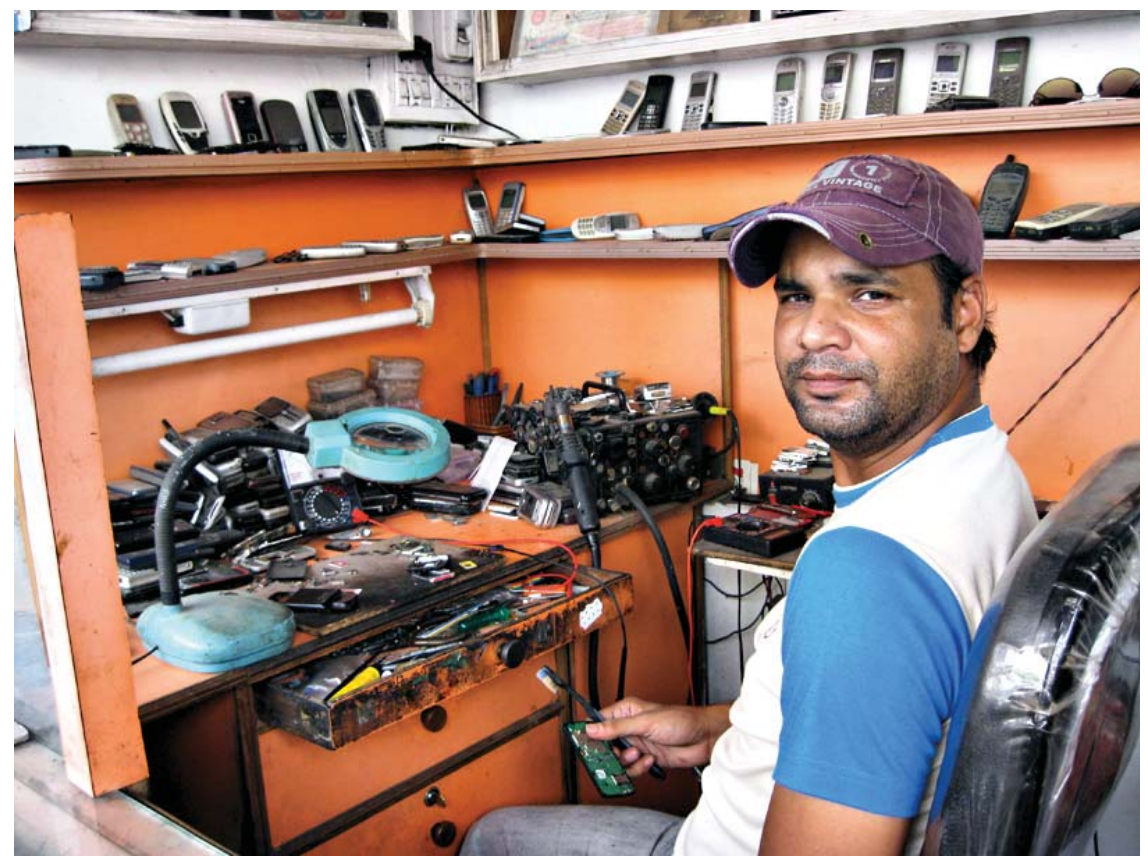

Figure B Mobile repair shop in Lucknow's bustling Hazratganj, June 2010

to his bare feet. A toothbrush was used to clean and dry the board before reassembly. Charging about Rs 100 to fix the most common faults, Saif earned on average Rs 800-1,000 a day. During intervals when no customers were hovering over the counter in anticipation of their device being fixed, Saif might turn to the more challenging cases: those that required more careful diagnosis and repair. There was a computer in a corner of the shop, which Saif used for software reformatting and downloading songs, wallpapers, video-clips and films. He charged about Rs 50 for 1 gigabyte of memory download.

Most of Saif's clientele came to him for handset repairs. Many customers belonged to Saif's Sunni community, confirming an observation of Nimmi Rangaswamy and Sumitra Nair that small businesses draw on community and kin networks. ${ }^{24}$ According to Saif, his clients were mostly men because, even if the mobile was used by a woman, it was the men in the house who had the responsibility for maintaining and fixing household electronics. And the stalls of the streets were male-dominated public spaces.

24 Nimmi Rangaswamy and Sumitra Nair, "The Mobile Phone Store Ecology in a Mumbai Slum Community: Hybrid Networks for Enterprise," Information Technologies $\mathcal{E}$ International Development 6 , no. 3 (2010): 51-65. 
Sometimes, when he was unable to repair a device, Saif consulted his friend who had more experience and worked in a nearby mobile phone shop that sold various branded and Indian mobiles. If Saif could not fix the problem, clients were not asked to pay. Indeed, Saif might offer to purchase the handset if its parts were useful. Otherwise clients might opt to try to repair it elsewhere.

Towns and cities in Uttar Pradesh were saturated with similar small businesses retailing mobile phones and associated products. "Grey markets" harboured more specialized outlets. There, one could find a string of shops and make-shift stalls that dealt exclusively with repairing mobile phones, both the hardware and software. In Banaras as in Lucknow, the mistriis in the grey markets were credited with being experts, and if the neighbourhood mistri was not up to the task of fixing a handset, he would refer it to the "higher authorities" located in the grey markets. In Banaras that meant the Daal Mandi market located in the older part of town.

\section{Grey markets, grey phones}

The mobile phone section in the Daal Mandi market in Banaras emerged out of the thriving electronic media section, featuring pirated DVDs/VCDs/ CDs, TVs and other electronics. This area is dominated by Muslims, who trade mostly in non-branded phones, known as "China Mobiles," and secondhand devices.

While most handsets, including branded ones, are made in China, the term China Mobile refers to non-branded, ostentatious handsets. These mobile phones are considerably cheaper, and may feature (or claim to feature) many of the multimedia functions of branded phones, some even promising much more, such as a 30-day battery back-up, 8-megapixel cameras and TV reception. Their design imitates the branded devices. These stalls and shops offer an almost infinite pool of components for replacing and cross-fertilizing other mobile phones. ${ }^{25}$

For example, "G'five," a handset model, has batteries, screens and other components which easily fit into various Nokia or Samsung models, thus making factory-original components less necessary.

Most famously, however, it was the China Mobiles that initially featured the two and three-SIM card handsets. While Rangaswamy observes (this issue) that the dual SIM device is used across the class divide for a variety of purposes, it remains a particularly attractive feature for poorer consumers who often alternate between SIM cards to save money on calls. More recently, some major brands, including Nokia, have introduced double SIM models,

25 See Barendregt's term "cannibal phones" to describe the reconditioned phones circulating in the black markets of Indonesia. Bart Barendregt, "Sex, Cannibals, and the Language of Cool: Indonesian Tales of the Phone and Modernity," The Information Society 24, no. 3 (2008): 160-170. 
following the popularity of such devices in the China Mobile market. Unlike their legitimate relatives, China Mobiles are sold with no guarantee or warranty, or bill of purchase; thus the retailer does not have to pay VAT (value added tax). Their price is much lower, not only because they are non-branded and of lower quality, but also because they are not connected to any service centres.

The service and repair provided in this grey market economy is vital for a number of reasons. First, because these orphaned China Mobiles come without warranties, repair-walas and their stalls provide the only way of fixing a cheap phone. And many branded mobiles that do have warranties also end up with the repair-walas. As suggested earlier, although branded mobiles such as Nokia, Samsung, LG and so on are popular amongst the lower classes, the services associated with these products often seem inaccessible. Moreover, once a mobile is tampered with, not only is the warranty void, but it is instantly rendered an "untouchable item" by the branded service provider who will refuse to fix it.

In practical terms, the modern service centres are generally located far from people's neighbourhoods; it takes time and money to visit them. Equally important, the conduct of business at the repair-wala's is familiar; the formal care centre can be forbidding and alienating. Finally, the enormous uptake of mobile phones in India means that there are not enough specialized

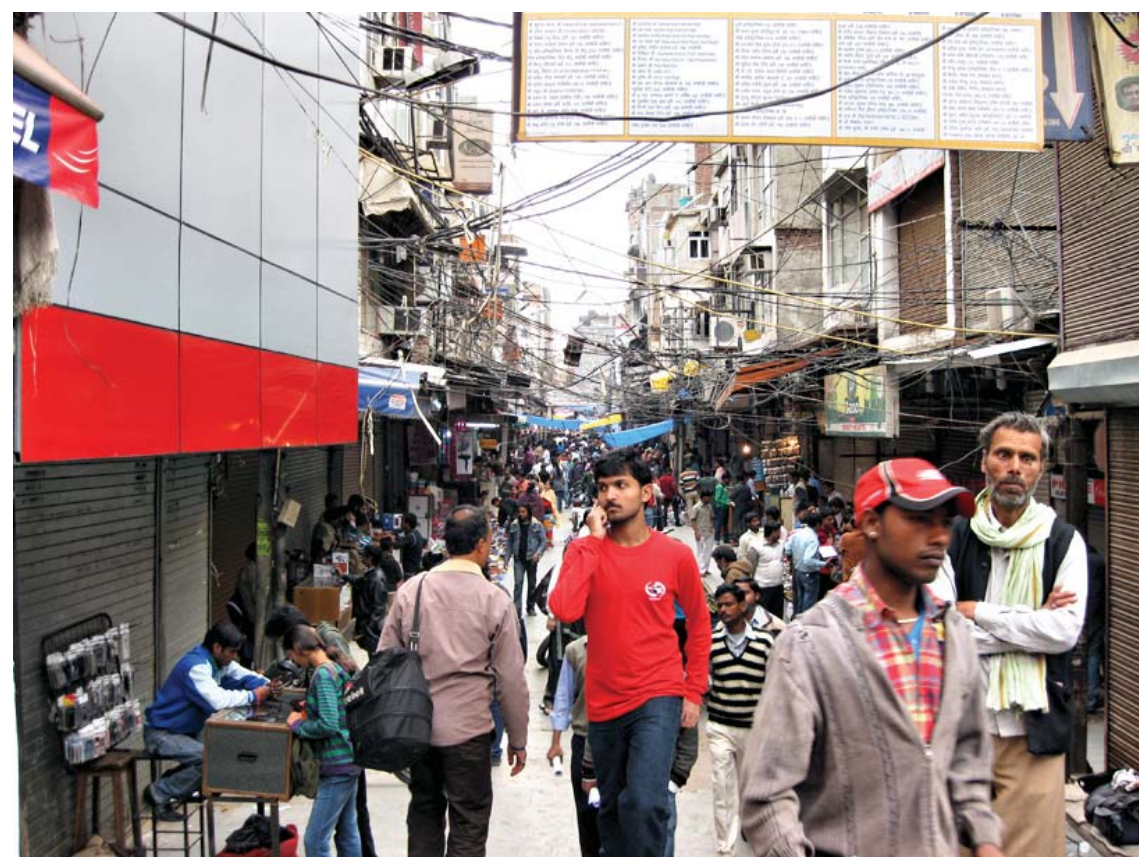

Figure C Gaffar Market: the hub of mobile phone repairing in north India. Delhi, February 2011 
repair centres to service the masses, thus making the "formal" and "informal" economy mutually dependent.

These grey markets feature a wide range of digital commodities, circulating between the centre to the periphery, with many of the small entrepreneurs procuring their supplies of mobile phones from larger markets in Delhi and Mumbai. For example, in Banaras, Arif and his brother, who operate a small shop in Daal Mandi, explained that they purchase their merchandise from Gaffar market in Delhi. Their small shop had around 40 Chinese-made mobile phones in all ranges, with various prices. Arif sells around 10 sets a day, with an average set costing Rs 1,500. There is a constant flow of customers inspecting and comparing stalls and negotiating prices. For these people this is an attractive and familiar way to shop, where the consumer wields significant power.

In Banaras' Daal Mandi the cost and types of a handset varied slightly across the 30-odd stalls in the vicinity of Arif's shop. Business was thriving, not only amongst the retailers but also in the repair business, located less than fifty metres up the narrow lanes.

\section{The craft of repair}

While recent studies describe the markets for low-end goods, relatively little is known about the people who are charged with resurrecting or extending the life expectancy of such goods - the mistriis — and about the way they learn their skills. Rangaswamy and Nair report on store owners in slums in Mumbai, some of whom trained in repairing mobile phones through formal courses at institutes charging about US $\$ 300$ for a four-month course. As they observe, for people living in the Mumbai slums of Behram Baug such sums are substantial, and for most an additional period was required in which they engaged in "self-training on the job" or supplemented "their training through peer-learning." 26

My findings confirm these observations. While many of the street-repairers were trained by their peers and gain proficiency on the job, the most competent ones had some sort of formal training in an institute [see figure D]. In some instances, I was told, a family might invest in one member to train at an institute so that he can then return and pass on the knowledge to his community and kin network. However, as the following section demonstrates, in the context of the repair economies, terms such as "peer learning" and "formal training" require further explanation.

The repair industry was highly competitive, and informants explained that they only shared their knowledge with close kin and friends. This had implications for the way they conducted their trade and improved their skills. According to one repairman in Banaras, when he sent mobiles that he was

26 Rangaswamy and Nair, "The Mobile Phone Store Ecology," 62 


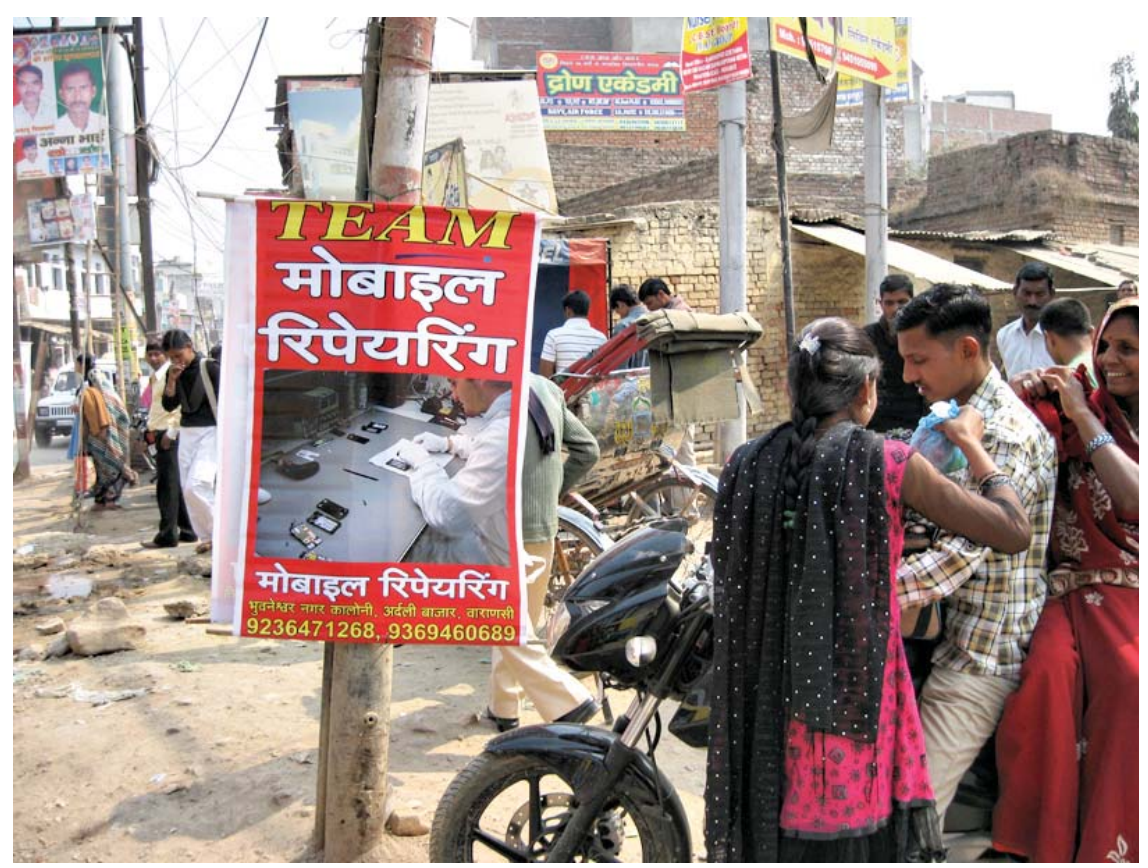

Figure D Ad for mobile-repairing course, Banaras (Varanasi), February 2010

unable to repair to Daal Mandi, he marked the components with microscopic precision so that the repairers in Daal Mandi did not replace them with used parts. He explained that these more skilled repairers jealously guarded their knowledge, restricted access to their shops and barred others from viewing their work. The microscopic marking had another function: to increase his skills in identifying the source of a problem. He would mark several suspect components in the faulty device, and when the expert returned the repaired mobile, he would open it, not only to ensure no used parts had been inserted, but also to try to identify the fault by checking which of the marked components had been tinkered with. "Peer learning" could be by stealth as much as by sharing.

There are varying degrees of formality in the training process. ${ }^{27}$ Informal training could be gained by apprenticing in a shop or learning from peers, while the formal acquisition of skills was more systematic. For example, when I asked a 17-year-old repairman in a small mobile phone shop about his training, he referred me to his teacher located near the Banaras city centre. The teacher's place was tucked in a small passageway next to a few photography shops and a number of mobile-phone shops. The teacher, Harpeet Singh,

27 See Leela Fernandes, India's New Middle Class, 98-100. 


\section{Consumption, Technology and Adaptation}

was a soft-spoken man in his early 30 s who said he gained his skills by watching others and through reading repair manuals. His shop contained all sorts of mobile phone accessories and parts, but Harpeet spent most of his day doing repairs, which he enjoyed because of the challenges they posed. For several years he had conducted courses for young men who wanted to learn repairing. According to Harpeet, mobile repairing was an especially productive option for young men who would otherwise be in limbo or relying on the government employment schemes, such as MNREGA (Mahatma Gandhi National Rural Employment Guarantee ACT), which offered only a wage of Rs 100 a day. Harpeet had trained more than 60 students; all had found jobs; and some had opened their own repair business. The course lasted about three months, for which he charged Rs 8,000 (US \$160). The timing was flexible, but the student attended around three hours a day. The course began with a few weeks of instruction about the hardware and identification and repair of faults, followed by study of software repair programs and techniques. After the course the student usually spent a few weeks with Harpeet to gain onthe-job experience.

Harpeet had a number of large books that he regularly ordered from Jaipur's G Tech publishing and that could also be purchased in Daal Mandi. These soft-cover books offered a range of mobile repair solutions from various tool kits to highly detailed diagrams of mobile-phone circuits, parts and fault-finding techniques. Other books were specific to downloading and software solutions. The books were in Hindi and English and featured the latest cell-phone models, ranging from Blackberry, Nokia and Samsung to the unbranded China Mobiles.

The software program most commonly used to unlock and revive mobiles was the UFS3, specific to Nokia models. For most other devices, including Samsung, LG and Indian brands, such as Spice and Karbonn, as well as China Mobiles, the commonly used software was known as SpiderMan. Harpeet added that one should be cautious when using software as one could easily alter the IMEI number. ${ }^{28}$ This could be dangerous since mobile phones attracted both terrorists and security forces, and, in any case, tampering with a phone's unique identification number was illegal and could result in unwanted attention.

Given the primacy of the mobile phone as the predominant consumer good in India, it is not surprising that repairing these devices is a profession in high demand. There was a mushrooming of training institutes. The best

28 The International Mobile Equipment Identity (IMEI) number is unique to each mobile phone and functions like an electronic fingerprint which is transmitted every time a handset is used, revealing the identity of the mobile handset. The IMEI number is generally found beneath the battery on the back of the handset. Many China Mobiles and smuggled phones had fake IMEI numbers until the Indian government declared that for security reasons these phones should be barred from the networks. From late 2009, all unregistered IMEI numbers were blocked and disconnected. 


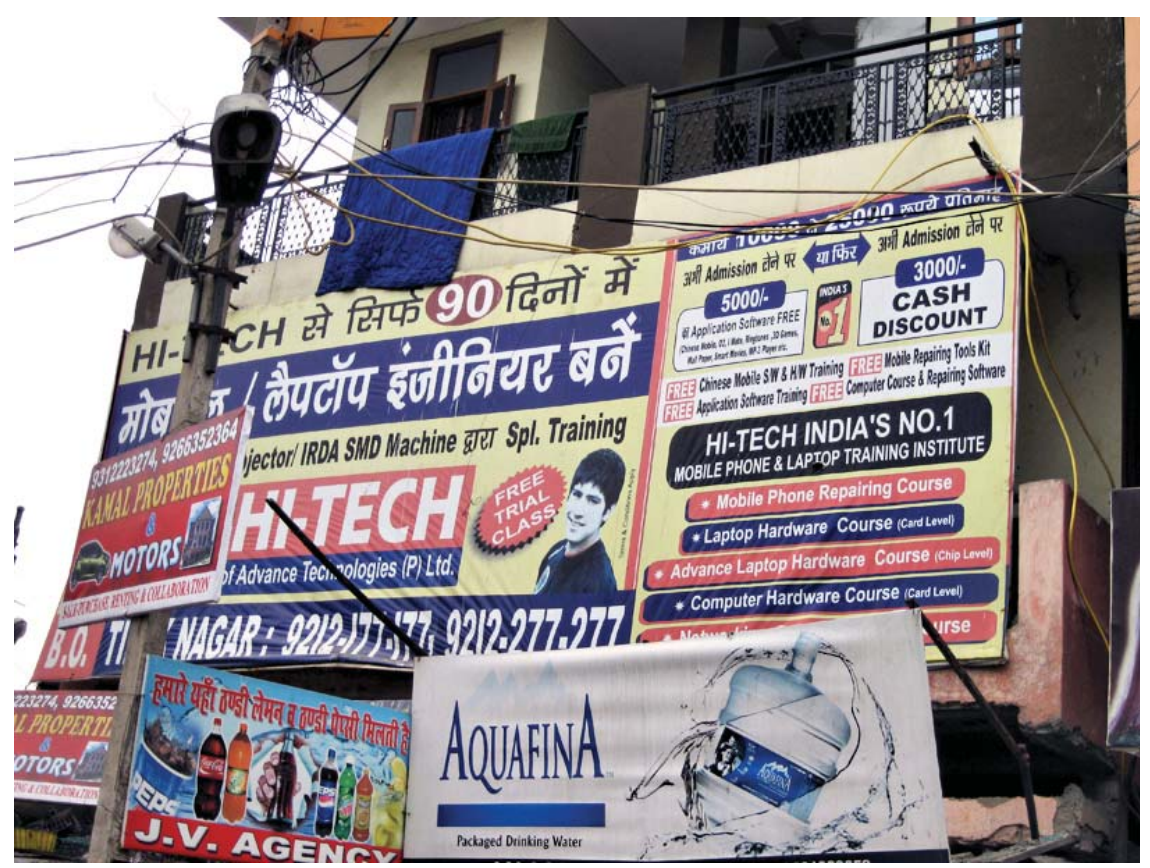

Figure E Billboard advertising a local branch of Hi-Tech institute for mobile-repairing courses, Delhi, February 2011

known in north India was the franchised Hi-Tech Institute of Advance Technologies, established in 2004 in Karol Bagh's Gaffar Market in Delhi. In 2011 the Hi-Tech Institute had more than two dozen outlets across north India, as well as one in Nepal (see figure E). It generated imitators: a host of smaller local institutes that offered similar courses and diplomas. The duration of such a course was about three months at a cost of between Rs10,000-12,000 (US \$200-\$240). Teaching was in batches of two-hour classes across the day. It was almost exclusively a male profession. Many of the young students were from the towns and villages of Uttar Pradesh; they were the first from their rural families to move out of agriculture. They viewed mobile repair as an attractive job opportunity for which many were willing to cycle $40 \mathrm{~km}$ a day from their villages.

According to the proprietor of a training institute, all students would find work quickly and with an average salary of Rs 8,000 (US \$160) per month. The most successful students advanced to work as engineers in the service centres of brand-name mobiles, such as Motorola and LG, or in the largest and most developed Nokia Care Centres. Deepak Kumar found work in one of the three Nokia centres in Banaras. A former student of Alpha Institute, one of several such institutes in the city, he explained his progress in the industry. After completing training at the age of 21, he gained further experience as an employee for a local mobile repair shop. He went on to 
work for Motorola for nine months, followed by a shorter period at an LG service centre. He subsequently decided to take the entry exams to become a Nokia technician. The exams, he explained, took place over a period of five days where the applicants were presented with the task of repairing 200 handsets. After passing this exam he began work as a junior technician on Rs 10,000 a month. Nokia updated the training of employees as new models were released by conducting one-day workshops, usually in one of the main hotels of Banaras. Over the next five years Deepak advanced to become head engineer, supervising more than 30 junior engineers and 20 "Care officers" in Banaras' largest Nokia Care Centre in the locality of Sigra. Deepak said that later he resigned over differences with a superior, and in March 2010 he opened his own shop selling mobile phones and accessories and offering repairs and servicing.

The intermingling of "informal" and "formal" sectors extends beyond individuals. All the training institutes that I visited offered courses that taught how to break into mobile phones and reformat them. The techniques relied on the non-copyrighted manuals described earlier and illegal software such as SpiderMan Box. The headquarters of north India's most successful mobile repair institute, Hi Tech, was located in New Delhi's Gaffar Market, the heart of the grey economy. There was thus a constant flow between the authorized and unauthorized sectors: service centres for brand-name phones relied on such institutions to train potential technicians, who might later work for a multi-national company.

\section{Conclusion}

The essay began by detailing my experiences at the Nokia Care Centre in Banaras. I argued such mobile care centres are as much symbolic as functional. In such places one is guided through the protocols of modern consumption. These protocols and modes of dress and address allow the middle classes to segregate themselves from others, mark their distinction and gain certitude about the solution of their problem. Spaces such as Nokia Care are both a product and reflection of middle-class aspirations and desires, increasingly in tune with global consumer capitalism. At the same time, these centres are also ways of imparting "middle class" or global values/norms to the aspiring classes, those who are moving out of rurality, illiteracy, poverty and low status.

The popularity of mobile phones has also brought the idea of warranty to a much wider population, yet the majority are still reliant on a highly developed repair economy to service their goods. India has over 900 million mobile phone users, few of whom rely on product warranties, while illicit service providers systematically breach copyright laws, and refurbish mobiles with unauthorized components and software. Large numbers of people are buying into practices of warranties and the formal contracts that accompany them. But still larger numbers are demystifying these contractual taboos in 
a rational way: they break seals, look inside, study the workings and educate people in the craft of repair.

What may initially seem like competing and distinct economies (modern/ traditional; formal/informal) are in effect interdependent, characterized by overlaps and cross-fertilizations. Deepak Kumar's career path from mistri to a uniformed Nokia engineer is a case in point, as are the clone-mobile parts retrieved from "China Mobile" and inserted into the refurbished branded devices. The "local" and the "global" meld into each other; products lose their identities with specific territories; and arguments about the universality of consumer technologies and the experience of digital media are challenged. ${ }^{29}$ This is evident when we consider the complex repair chain of the consumption cycle, which involves "street side" repair, disaggregation and re-aggregation (i.e., part swapping and substitution), restoration, and recycling (figure $\mathrm{F}$ ).

Of course, many would argue that the repair economy servicing the poor is a consequence of cheap labour. Higher labour costs and patent rights, among other things, mean that even minor repairs in developed countries are very expensive, but this does not fully explain the behaviour of subaltern consumers in India. As India becomes a player in the global market it is called on to follow the rules of consumer capitalism. The state is trying to establish laws, institutions and values that correspond to a world order shaped by multinational corporations. Yet in India the applicability and appeal of such universalizing consumer-capitalist systems and legal measures are, so far, partial at best.

In a country where the majority of people have mobile phones, there is a question of scale as much as of socio-economic structures and local circumstance. For the poor, the material environment is less secure, with a higher degree of wear and tear on mobiles, which is why street-side assistance is so prevalent. This street-side maintenance and "grooming" of the mobile phone enables the consumer to re-energize, revitalize, update, repair and personalize the device with new components, such as screens, batteries, software, new tunes, screensavers and various downloads. The insurance policy, such as the warranty, is thus replaced by social networks of people, places and structures that offer a degree of familiarity in what is a precarious existence. One must not romanticize this street-side repair as a collective resistance to consumer capitalism, and this repair economy has its own politics and competitive environment. The two economies operate side-byside. The small mobile shops and entrepreneurs are connected through various networks of repair, mobile accessories and handsets to global networks and brands. The MNCs also rely on this "informal" economy to supplement their services and draw from an increasing pool of skilled mistriis who, when

29 Gabriella Coleman, "Ethnographic Approaches to Digital Media," Annual Review of Anthropology 39 (2010): 487-505. 


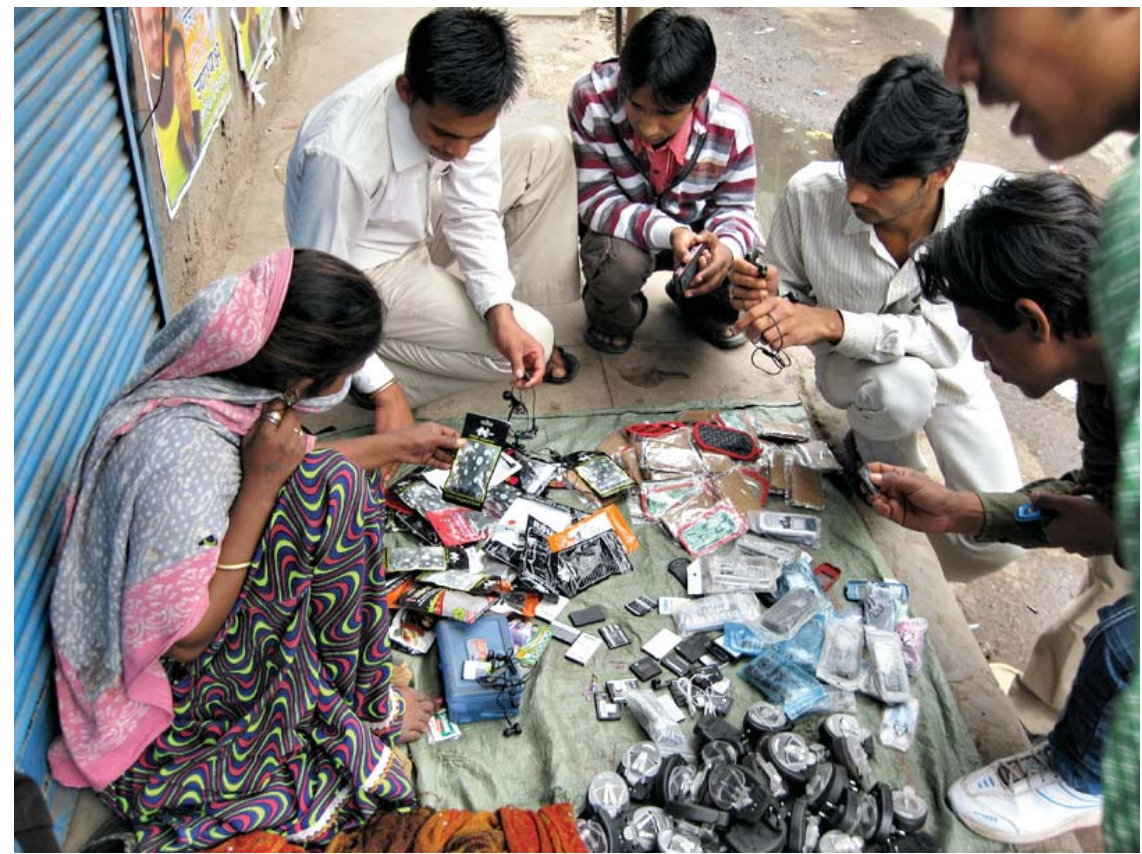

Figure F Street-side selling of mobile phone paraphernalia, Delhi, February 2011

entering the gates of Nokia, are re-branded as mobile-phone engineers. No doubt, as many studies have shown, globalization and consumer capitalism carry with them their discontents and in some cases serve to marginalize and exclude the poor from participating and sharing in their produce. Yet by operating in this manner, consumers evade the full impact of a capitalist economy premised on inbuilt obsolescence. Within the repair economy "things" can last; this economy of care stabilizes or mitigates risks. The repair economy may not provide rapid mobility and advantage, but it offers those with low purchasing power and status participation in the global system.

Australian National University, Australia, May 2012 